\title{
Does Longer Instruction Time In School Improve Children's Performance? An Assessment of Perception of Parents and Teachers inAbakaliki South-Eastern Nigeria
}

\author{
Chinonyelum T. Ezeonu, ${ }^{1}$ Onyinye U. Anyanwu, ${ }^{2}$ Maria N. Anyansi, ${ }^{3}$ \\ Theresa N. Nnaji, ${ }^{2}$ \\ ${ }^{1 .}$ Department of Pediatrics, Ebonyi State University, Abakaliki, 480001, Nigeria \\ 2. Department of Pediatrics, Federal Teaching Hospital, Abakaliki, 480001, Nigeria \\ ${ }^{3 .}$ Department of Nursing Sciences, Ebonyi State University, Abakaliki., 480001, Nigeria
}

\begin{abstract}
:
Background; Over the past decades, it has been a tradition for primary schools to operate a 6hr/day instruction time schedule. The tradition is gradually waning as it can be observed that some schools have extended their school instruction time to bout 7 - 8hrs/day. There are controversies surrounding this move in terms of benefits and losses. Time has been considered as a very important factor in teaching and learning. Some authorities lay emphasis more on the quality use of time than the quantity of time.

Method; A descriptive cross-sectional study of the opinion of about two hundred and one adults randomly selected in Abakaliki was doneusingLikert scale rated questionnaires.

Result;Most of the respondents were not confident that longer school instruction time yielded better academic performance or guaranteed better academic performance, neither did they consider it a waste of time. A majority agreed that it allowed parents more time at work.

Conclusion; Educators and policy makers may mean well for the pupils by proposing longer school instruction hours but optimal use of the time and careful consideration of need is more important to education policy.
\end{abstract}

Keywords; Primary schools, Instruction time, policies, academic performance

\section{Introduction}

Compulsory instruction time refers to the amount of instruction time that almost every school has to provide and almost every student must attend ${ }^{1}$. In the developed countries, instruction time in schools varyfrom country to country depending on levels of education. Countries with fewer numbers of weeks for teaching in a session, practice longer instruction time per day, whereas countries with more weeks of teaching, practice shorter instruction time per day. [1] Over the past decades, it had been a tradition for primary schools to operate a $6 \mathrm{hr} /$ day instruction time schedule whereby classes generally begin by $8 \mathrm{am}$ and dismiss by $2.00 \mathrm{pm}$. Currently, the tradition is gradually waning as it can be observed that some schools, particularly private schools, begin classes by $8 \mathrm{am}$ and dismiss around $4 \mathrm{pm}$ amounting to $8 \mathrm{hrs} / \mathrm{day}$ instruction time. Educators, policy makers and community activists have pushed and added more instructional time to children at school due to the fear that the standard 6hrs does not offer enough time to prepare students for a successful future. [2] It was the President of the United States of America, Barack Obama, who once said, " We can no longer, afford an academic calendar designed when America was a nation of farmers who needed their children at home, ploughing the land at the end of each day, the challenges of the new century, demands more time in the classroom."[3] Interestingly, several authors across the globe have debated for and against longer school instruction hours in a day. Caroll's theory emphasizes that students will be successful if there is sufficient time spent on what is to be learned using her model equation to explain that the degree of learning depends on the time allocated for learning, time engaged in learning, time needed to learn, quality of instrument and the pupil's ability to understand. [4] This theory brings to mind that school time should be considered in its three forms, namely, time allocated, time engaged and time needed to learn. Gromeda and colleagues described the various forms of time. [5] He noted that allocated instruction time which is the time apportioned by the school from beginning to the end of classes is affected by factors such as student or teacher lateness or absenteeism and that engaged time which is the time during which the student is actually paying attention is affected by the teaching materials or method. The importance of time for improved academic performance have been supported by some authors.[6,7] while some others stress that merely increasing instruction time will not improve academic performance but that family inputs, innate ability and quality of teaching would positively affect academic performance. $[8,9]$ Deciding on the amount of instruction time and its organization is a key decision for policy makers. [5]There is thus an ongoing policy debate whereby the proponents of longer school instruction time 
emphasize on the importance of time for effective teaching and learning while the opponents of longer school hours emphasize quality use of available time to deliver the same information to pupils.

Longer instruction time has become a norm in most primary schools especially the private owned schools. The stakeholders in this business include the parents, the children and their teachers. In service delivery, it is necessary to once in a while evaluate the perception of the consumers about the product or service delivered in order to determine the need for improvement, for continuity or for cessation of the service. We carried out this research to at least appreciate the perception of the general populace about longer school hours in primary schools with specific reference to its yielding better academic performance, guaranteeing better academic performance, being useful for weaker students or being a waste of time. The findings from this study will not only assist teachers and school administrators but will also assist policy makers in enacting educational policies.Within the capacity of our search, no similar study has been conducted in Ebonyi,or in Nigeria. There is a dearth of literature on the benefits or disadvantages of longer instruction hours in Nigeria.

\section{Methodology}

This was a descriptive cross-sectional study. This study was carried out in Abakaliki, the capital of Ebonyi state, southeastern Nigeria. This area is an urban area. This was chosen since our our preliminary investigation indicated that longer instruction hours was common practice in urban schools particularly the private owned schools which were greater in number in the urban areas. This area is populated by civil servants, traders and few farmers. With increasing urbanization, Abakaliki is endowed with a lot of primary schools, about 16 public/government owned and more than 20 privately owned primary schools.

About two hundred and twenty individuals aged 25-60years of various occupations in Abakaliki were randomly selected for this study and the inclusion criteria being that he or she must have or have had school children and is capable of giving necessary information. The study tool was a semi-structured questionnaire consisting of bio-data of the respondent and other questions designed to assess the perception of the respondent about longer school instruction time in primary education. The responses were structured using a five point Likert's scale graded as (1) Disagree totally ; (2) Disagree; (3) Agree partially; (4) Agree; (5) Agree totally .

Ethical approval was obtained from the Ebonyi State University Research Ethics committee and informed consent was obtained from each participant before administering the questionnaires. The participants were assured of the confidentiality of their responses and maintenance of anonymity. In order to ascertain the validity of the instrument, the questionnaire was presented to three independent experts in the field of education for analysis. A pilot study was conducted using about 20 respondents. This was to ensure clarity of the questions and that the instrument measures the exact construct needed for the study. Necessary corrections and adjustments were made afterwards before production of the final draft of the questionnaire.

The questionnaire was administered directly to the respondents at various convenient places, in the school, in the offices, at gatherings and at convenient times for the respondent. Some of the respondents who needed guidance were readily assisted. About 220 questionnaires were administered, but only 201 were used for data analysis because the others were inappropriately filled. Data was analyzed using SPSS version 20 statistical package. With this, case summaries including the mean, median and mode of the various responses were determined. Comparison of means with respect to the various occupations, level of education and gender was done using the one-way ANOVA. The set level of significance is $p<0.05$.

\section{Result}

From Table 1 presented, there were more female respondents $(75.7 \%)$ than males $(24.3 \%)$ and a majority of the participants were between $25-34$ years of age. There was a slightly fair distribution of the occupation except for the house wives and the applicants. The house wives refer to mothers who stay back home, full time to take care of the home, whereas the applicants are those who are actually seeking job. A total of sixty two school teachers participated in this research. About $61.9 \%$ of the participants had tertiary education.

TABLE 2 presents a summary of the responses to all the questions administered, with the mean representing the most likely or average response of the individuals.At a mean response of 3.1 and 3.3, most participants partially agreed that longer instruction time yields better academic performance and guarantees better academic performance. However, these responses varied across sex and levels of education as most females partially agreed to better academic performance and whereas most males disagreed. Those with lower levels of education agreed that it guaranteed better academic performance whereas those at the tertiary level of education disagreed. This difference was statistically significant (TABLE 3). On same question, across occupations, most of the teachers' responses were between disagreement and partial agreement. Generally, participants partially agreed (3.2) that longer school hour was seen to be beneficial to the weaker students but more strongly from participants with primary level of education (mean 4.3).Majority did not agree it was a waste of time (mean response 2.3) more so amongst female respondents (mean 2.1) than the male respondents (mean 2.8). 
Does Longer Instruction Time In School Improve Children's Performance? An Assessment of ..

\section{Discussion of the findings}

This study depicts the different ways people perceive the practice of longer school instruction time in primary education. Most of the respondents were not confident that longer school instruction time yielded better academic performance or guaranteed better academic performance neither did they consider it a waste of time. It is presumed that the primary aim of introducing longer instruction time in some schools is to improve the pupils' academic achievement. This study therefore leaves room for one to wonder if the aim is being achieved or appreciated. Parents are in the better position to tell the effect of longer school instruction time on their children. This probably supports Lavy's point that assessing the effect of longer school hours will depend on various subjective factors such as the pupil's ability, parental background and available school resources and not just the length of time spent at school. [10] It was even more interesting to find that teachers, most civil servants and all those with tertiary level of education, were particularly the ones that did not agree that longer school hours yielded a better academic performance. Although we did not give room for explanation of answers we could feel from these class of respondents that parental background and ability to assist in teaching their children at home was more important for better academic performance.

From our study, it was obvious that most participants agreed that longer instruction allowed parents more time for work. Gromeda and colleagues in their work found that those whom by virtue of their economic status or nature of work, who needed to struggle to provide after-school care for their children seemed to be more compatible with longer school instruction time. [5] This in a way buttresses the report on America after $3 \mathrm{pm}$ which values longer school instruction time in the form of after-school program as a useful way of childminding until the parents were back from work. [11] This is well appreciated but the question becomes, could the extension of school instruction time be a child minding option or rather, the stakeholders really interested in the quantity or quality of school time? Most of the participants agreed that longer school instruction time did help weaker students. This opinion differs from that of some authors who stated that a school day which is too long, may leave struggling students little time to catch up, whereas the same total hours distributed over more weeks of school would offer greater flexibility. [12] There is no doubt that there is no existing consensus opinion regarding the need for extended school instruction time hence countries need to decide not just the number of instruction hours but the way in which the hours are distributed over the school year, in order to maximize learning outcome.

Most respondents agreed that longer school hours denied children adequate sleep thereby supporting Gewertz who noted that longer school hours may make children stay up in their night wear up to 2 am trying to finish their homework, having spent a long day learning at school. [2]Indeed, deficient sleep has been shown to impair memory, attention, reaction time, mood and divergent thinking. $[13,14]$ This is supported by Touitou and Begue who advocated that the school system should respect biological rhythms by keeping to 4-6hrs instruction time in primary school. [15]

Patall and co-workers did a great work in their systematic review of literature from 1985-2009, on the effects of extending instruction hours in schools and outlined some potential advantages and disadvantages to different stakeholders; the students, teachers, parents and society. [16] They found that longer instruction hours increased learning, better academic achievement and deeper coverage of curriculum to the students. It gave teachers more time to cover the curricula, gave parents room for better scheduling and transport costs as they could spend more hours at work while the kids were in school. To the society, it was beneficial to the socially disadvantaged who could not afford extra lessons at home. On the other hand, they found, it could be time wasting, increased fatigue and boredom on students, leaving less time to do other activities. It led to teacher burn out and denied parents the opportunity to meet up with child care needs. To the society, the disadvantage found was that it takes resources away from more effective interaction and quality instruments of teaching. ${ }^{16}$ Educators and policy makers may mean well for the pupils by proposing longer school hours but matching resources with students' needs and making optimal use of the time are central to education policy. [1] Factors that actually influence the productivity of instruction hours include the quality of the curriculum, the teaching method/quality, and the effectiveness of the overall education system. [17] The international evidence, based on self-evaluation, seems to suggest benefits occur most from high quality teacher led activities for sustained periods of time and that simply extending time spent in school does not necessarily increase either engaged time (when pupils are focused on the task in a lesson) or academic learning time (when learning is happening). [18]It is thus the quality of regular school lessons not the quantity of learning hours that will improve academic performance.[19]

From the above discussion of findings and literature, the onus lies on every country to weigh the advantages and disadvantages as it concerns the various stake holders and come up with the most cost-effective policy. This matter deserves ethical consideration because children constitute a vulnerable group on whom this practice matters most. The ethics principles of beneficence, non-maleficence, autonomy and distributive justice need to be considered. Thus the critical questions on the effects of administering longer school hour on primary school pupils are; is it of any benefit, will it do any harm, does it respect child right and is it generally fair to all 
Does Longer Instruction Time In School Improve Children's Performance? An Assessment of ..

the stakeholders? In service delivery, it is only fair to once in a while evaluate the perception of the consumers about the product or service delivered in order to determine the need for improvement, need for continuity or still need for cessation of the service where or when necessary.

\section{Conclusion}

The responses given to most of the statements depict more of uncertainty about the importance of longer instruction time in primary schools. It is necessary for people to be convinced about what they do or what they are trying to do. By this study, it implies that schools that are practicing longer instruction time at school need to prove the worth of their program beyond reasonable doubts.

However, it is pertinent to note that this issue of time and academic achievement must not fail to consider the utility concept on the part of the teacher and the pupil. This is where to ask the question, where does one place factors such as the teacher's skills or ability to teach and the student's inherent capacity to learn. Do they always depend on time? Is it not possible that a highly skilled teacher can deliver the same information within a shorter time, with even a greater impact on the pupils, than a poorly skilled teacher, whom it may take more than a day/week to drive in the same information? The emphasis is thus on quality of education not just the quantity. Glewwe \& Kremer summarized this by saying that success in expanding the quantity of education in most developing countries has shifted attention to education quality. They were of the opinion that additional time to the traditional six hour period will be really a waste of time if the additional instructions given are of poor quality. [20] In all, there are variable factors which may affect teaching and learning, ranging from teacher's ability to teach, to pupil's capacity to learn. It requires a committed teacher to appreciate the need and the use of extra hours at school. The pupil or learner need to be able to absorb more information over the given period otherwise any extra time may actually be a waste of time.

Essentially, longer instruction time in primary schools may not make sense to a people when the benefits are not very obvious to them. The idea behind this project is to bring out policy implication of longer instruction time for schools in Ebonyi State and Nigeria generally. Should longer school hours be implemented as a policy in primary schools? If yes, what are the supporting facts? The people's responses so far has not given a clarifying opinion about the relevance of longer instruction time at school except for the fact that it allows parents more time at work, while the school minds the children.

Taking a quote from an article from the Organization of Economic Co-operation and Development (OECD) it says "The time spent in school is much less important than how the available time is spent, on which field of education it is spent, how motivated the students are to achieve, how strong the curriculum is and how good the teachers are. "[1] School administrators, policy makers and education activists must learn to appreciate the opinion of other stake holders, especially the consumers of the policy, before implementing a policy. Even when a policy has been made, it is important to monitor the activities, and evaluate the importance from time to time in order to determine the need for its continuation, improvement or withdrawal. Researchers are valuable in the field of situation analysis and situation reports. Hence policy makers must work with researchers to be able to obtain relevant facts as the decision on the amount of school instruction time is a key decision for policy makers.

\section{Limitations of the study}

This study is not without its limitations. Our sample size was limited to 201 respondents. A larger sample size from wider category of participants would have given a better outcome. We were unable to include an assessment of schools with different instruction times; to comparing those practicing longer school hours with schools not practicing longer school hours could have provided more insight to this study. We recommend this for future studies.

\section{Conflicts of interest; None}

\section{References}

[1]. OECD. Education in focus. How is learning time organized in Primary and Secondary education? (2016) www.oecd.org/edu/eag.htm (accessed on 8th Nov. 2016 from)

[2]. Gewert C. Consensus on Learning Time Builds. Educational Week. 2008: 28(5);1-4

[3]. Obama B. Speech given to the Hispanic Chamber of Commerce.2009 www.whitehouse.gov/the_press_office)

[4]. Caroll JBA. Model of school learning. Teachers college record. Harvard University, 1963;64: 723 -33.

[5]. Gromada A, Shewbridge C. "Student learning time; A literature review" OECD Education working papers, No127, 2016 OECD publishing Paris. http://dx.doi.org/10.1787/5ym409kqqkjh-en.

[6]. MassTeLLs. Massachusetts Teaching learning and leading survey. 2008. Accessible at www.masstells.org

[7]. Will D, Roland F. "Getting beneath the veil of effective schools. Evidence from New York City.NBER Working Paper. No 17632, December 2011

[8]. Hanushek, E. Publicly Provided Education.NBER Working Paper, 8799. Cambridge, MA: National Bureau of Economic Research.2002. Retrieved from: http://www.nber.org/papers/w8799

[9]. Hess FM. To fix Education; school hours and money need to be better spent. On the issue; American Enterprise institute for publishing policy research. 
[10]. Lavy V. Do difference in school's instruction time Explain International achievement gaps in Maths, Science and Language? Evidence from Developed and Developing Countries. Published by centre for the Economic of education, London School of economics, Houghton street, London, WC 2A 2E, 2010

[11]. Aliance A. America After 3pm. The most in-depth study of how Americas children spend their afternoon. www.afterschoolalliance.org/AA3_key_findings

(Assessed on 15th August, 2016)

[12]. OECD. Education indicators in Focus. How much time do primary and lower secondary students spend in the classroom? www.oecd.org/edu/eag/htm 2014. (accessed 14th August 2016)

[13]. Martin PR. Counting sheep. The science and pleasure of sleep and dreams. Harper Collins, London. 2003.

[14]. Hansen M, Jansen I, Schiff A, Zee PC, Dubocovich M. The impact of school daily schedule on adolescent sleep. Pediatrics. 2005; 115 (6): $1555-61$.

[15]. Touitou Y, Begue P. Organization of school time and children's health. Bulletin of the National Academy of Medicine. 2010 ; 194 (1):107 - 22

[16]. Patall E, Cooper H, Allen A.B; "Extending the School year. A systematic review of research (1985-2009)" Review of Educational Research, 2010, 80(3) pp 401-436.

[17]. Mullis IVS, Martin MO, Foy A, Arora A. PIRLS 2011 International Results in Mathematics, International Association for the Evaluation of Educational Achievement (IEA) Amsterdam and TIMSS \& PIRLS International study center, MA. $2012 \mathrm{~b}$.

[18]. Briggs A and Simons J. Only a matter of time? A framework for the most effective way to lengthen the school day in England. Policy Exchange. 12 Aug. 2014. Accessed on the $15^{\text {th }}$ of Nov. 2016 from https://policyexchange.org.uk

[19]. OECD. "Relationship between student learning time and performance 'In Quality time for students learning In and Out of school. OECD 2011, publishing. http://dx.doi.org/10.1787/9789264087057-6-en.

[20]. Glewwe P, Kremer M. Schools, teachers and education outcomes in developing countries. In: E. Hanushek\& F. Welch (Eds.), North Holland. Handbook of the Economics of Education: 2006; pp 945-1017.

VII. Tables

Table 1; Characteristics of the various respondents

\begin{tabular}{|c|c|}
\hline Respondent's personal data & No $(\%)$ of Respondents \\
\hline $\begin{array}{l}\text { Age (years) } \\
25-34 \\
35-44 \\
>45\end{array}$ & $\begin{array}{l}123(60.9) \\
52(25.7) \\
20(9.9)\end{array}$ \\
\hline $\begin{array}{l}\text { Gender } \\
\text { Male } \\
\text { Female }\end{array}$ & $\begin{array}{l}49(24.3) \\
153(75.7)\end{array}$ \\
\hline $\begin{array}{l}\text { No. of Kids } \\
1-2 \\
3-4 \\
>4 \\
\text { Nil }\end{array}$ & $\begin{array}{l}68(33.7) \\
52(26.2) \\
25(12.4) \\
47(23.3)\end{array}$ \\
\hline $\begin{array}{l}\text { Occupation } \\
\text { Civil Servant } \\
\text { Self employed } \\
\text { House wife } \\
\text { Applicant } \\
\text { Teachers }\end{array}$ & $\begin{array}{l}67(33.7) \\
50(24.8) \\
17(8.4) \\
4(2.0) \\
62(30.7)\end{array}$ \\
\hline $\begin{array}{l}\text { Level of education } \\
\text { Primary } \\
\text { Secondary } \\
\text { Tertiary }\end{array}$ & $\begin{array}{l}21(10.4) \\
51(25.2) \\
125(61.9)\end{array}$ \\
\hline
\end{tabular}

TABLE 2; Questions And The No. Of Respondents on Each Response Ratings And The Mean

\begin{tabular}{|c|c|c|c|c|}
\hline Question & $\begin{array}{l}\text { Total no. of } \\
\text { respondents }\end{array}$ & Mean & Median & $\begin{array}{l}\text { Range } 1-5(1= \\
\text { Disagree totally and } \\
5=\text { Agree totally })\end{array}$ \\
\hline $\begin{array}{l}\text { 1. It offers children the opportunity for greater } \\
\text { individual attention from their teachers }\end{array}$ & 201 & 3.1 & 3 & $1-5$ \\
\hline 2. It is useful for the weaker students & 201 & 3.2 & 3 & $1-5$ \\
\hline 3. It is better than paying for lesson teachers & 201 & 2.9 & 2 & $1-5$ \\
\hline $\begin{array}{l}\text { 4. It gives children the opportunity to have a wider range } \\
\text { of subjects in school }\end{array}$ & 201 & 3.3 & 4 & $1-5$ \\
\hline $\begin{array}{l}\text { 5. It gives teachers the opportunity to address more } \\
\text { challenging topics }\end{array}$ & 201 & 3.5 & 4 & $1-5$ \\
\hline $\begin{array}{l}\text { 6. It yields better academic performance than the } \\
\text { traditional } 6 \mathrm{hrs} \text { at school }\end{array}$ & 197 & 3.1 & 3 & $1-5$ \\
\hline 7. It does not guarantee better academic performance & 194 & 3.3 & 4 & $1-5$ \\
\hline 8. It is a waste of time & 195 & 2.3 & 2 & $1-5$ \\
\hline
\end{tabular}


Does Longer Instruction Time In School Improve Children's Performance? An Assessment of ..

Table 3; Variability of response with occupation, gender and level of education that longer school hours yield better academic performance

\begin{tabular}{|c|c|c|c|c|}
\hline Question & Category of respondent & Mean & p-value & $\begin{array}{l}\text { Range Scale of } 1= \\
\text { disagree totally to } 5= \\
\text { agree totally }\end{array}$ \\
\hline $\begin{array}{l}\text { It yields better academic } \\
\text { performance }\end{array}$ & $\begin{array}{l}\text { Male }(\mathrm{n}=49) \\
\text { Female }(\mathrm{n}=148) \\
\text { Level of education } \\
\text { Primary }(\mathrm{n}=21) \\
\text { Secondary }(\mathrm{n}=47) \\
\text { Tertiary }(\mathrm{n}=125) \\
\\
\text { Occupation } \\
\text { Civil Servant }(\mathrm{n}=67) \\
\text { Self-employed }(\mathrm{n}=46) \\
\text { Housewife }(\mathrm{n}=16) \\
\text { Applicant }(\mathrm{n}=4) \\
\text { Teacher }(\mathrm{n}=62)\end{array}$ & $\begin{array}{l}2.6 \\
3.3 \\
\\
4.2 \\
3.8 \\
2.6 \\
\\
\\
2.7 \\
4.1 \\
3.8 \\
5 \\
2.6\end{array}$ & $\begin{array}{l}0.002 \\
0.000 \\
0.000\end{array}$ & $\begin{array}{l}1-5 \\
1-5 \\
\\
1-5 \\
1-5 \\
1-5 \\
\\
\\
1-5 \\
1-5 \\
1-5 \\
1-5 \\
1-5\end{array}$ \\
\hline
\end{tabular}

Table 4: Variability of response with occupation, gender and level of education that longer school hour is beneficial to the weaker students

\begin{tabular}{|c|c|c|c|c|}
\hline Question & Category of respondent & Mean & p-value & $\begin{array}{l}\text { Range Scale of } 1=\text { disagree } \\
\text { totally to5= agree totally }\end{array}$ \\
\hline $\begin{array}{l}\text { It is beneficial to the } \\
\text { weaker students }\end{array}$ & $\begin{array}{l}\text { Male }(n=49) \\
\text { Female }(n=152) \\
\text { Level of education } \\
\text { Primary }(n=21) \\
\text { Secondary }(n=51) \\
\text { Tertiary }(n=125) \\
\text { Occupation } \\
\text { Civil Servant }(n=67) \\
\text { Self employed }(n=46) \\
\text { Housewife }(n=16) \\
\text { Applicant }(n=4) \\
\text { Teacher }(n=62)\end{array}$ & $\begin{array}{l}2.5 \\
3.4 \\
\\
4.3 \\
4.0 \\
2.6 \\
\\
\\
2.7 \\
4.0 \\
4.1 \\
5 \\
2.7\end{array}$ & $\begin{array}{l}0.00 \\
0.00 \\
0.00\end{array}$ & $\begin{array}{l}1-5 \\
1-5 \\
1-5 \\
1-5 \\
1-5 \\
\\
1-5 \\
1-5 \\
1-5 \\
1-5 \\
1-5\end{array}$ \\
\hline
\end{tabular}

